\section{Industry and research}

\section{Dupont joins in}

\section{Boston}

Reflecting the growing eagerness of industry and universities to find ways in which both can profit from advances in biotechnology, the chemical company Dupont has promised $\$ 6$ million for genetic engineering research to a group of workers at Massachusetts General Hospital, one of the teaching hospitals associated with Harvard University. This announcement comes just as scientists, politicians and university administrators are completing their examination of a ten-year, $\$ 50$ million grant to another group of Harvard geneticists proposed by the German pharmaceutical house Hoechst-Roussel (see Nature 18 June, p. 525).

The Dupont grant will support the new genetics department at the Harvard Medical School under Dr Philip Leder who is moving to Harvard in September from the National Institutes of Health. The conditions of the Dupont deal are similar to the Hoechst arrangement; the grant recipients retain patent rights on discoveries made with corporate funds, but the companies are given exclusive licences to develop any products that result. One difference in the Dupont grant is that the company has not requested training positions for its scientists.

Although most university officials applaud these agreements, in the past month committees in both the Senate and the House of Representatives, of ficials of the National Institutes of Health and high ranking university officials from the United States and Canada have met independently to review Harvard's new affiliations with industry and to question whether the quality and independence of research will be compromised by corporate support.

These hearings have attracted wide attention since Senator William Hatch complained that the Harvard-Hoechst grant fostered a "technology leak" by giving a German company first crack at exploiting discoveries at institutions supported by public funds. The victims of such a situation, he suggested, would be the US taxpayers who have indirectly supported basic research that will benefit foreign investors.

This concern will not be a problem with the Dupont grant, because the money will be coming from a US chemical and drug conglomerate. Dupont plans to give Harvard the \$6 million in annual instalments, with $\$ 2$ million immediately and $\$ 1$ million over each of the next four years.

University officials say that they will examine all patentable discoveries very carefully to determine whether they were made with federal funds or portions of the Dupont grant. Only the latter will bring Dupont exclusive licensing rights to university-owned patents.

The toughest scrutiny, however, may come from the local city councils. The Cambridge City Council has officially ordered an investigation of Harvard genesplicing experiments in tax-exempt laboratories. Council members intend to rescind tax exemptions where private corporations will reap financial benefits.

Harvard officials do not anticipate an investigation of the Dupont grant similar to the House investigation of the Massachusetts General Hospital-Hoechst agreement.

Michael D. Stein

\section{Chinese Academy of Sciences Scientist takes over}

China's Academy of Sciences once more has a scientist at its head. A few weeks ago the academy's Scientific Council met for the first time for 21 years and elected as its president Dr Lu Jiaxi, a physicist, who at one time worked at University College London under Professor S. Sugden and at the California Institute of Technology under Linus Pauling.

Dr Lu takes over the presidency from Fang $\mathrm{Yi}$, the minister responsible for the State Commission for Science and Technology. On resigning, Minister Fang stressed that the presidency should be an elected post (he had been a government appointee) and should go to a scientist.

At the same meeting, the Scientific Council accepted a draft constitution which states that the supreme decisionmaking power for the academy will be vested in the 400 -strong council, which from now on should meet every two years. Between council meetings, the academy will be administered by a presidium of 30 members, of whom 20 will be members of the council and 10 from the Communist party and government departments.

These changes reflect an overall policy of increasing the professionalism and prestige of Chinese science, which suffered considerably during the Cultural Revolution of 1966-1976. As well as revitalizing the Academy of Sciences, recent developments include the conversion of a teacher's training college in Hainan into a university, which will commence undergraduate enrolment in autumn 1983 and major discussions on how to develop vocational and technical secondary education. This latter need is so pressing that one government spokesman suggested that in addition to the state system, private projects for training technical workers should be encouraged. And to help young people develop their interest in science, a new "National Association of Science Coaches for Juveniles" was established in Peking, with Jiang Nanxiang, the Minister of Education as Honorary Chairman, and Wu Zhonghua, executive chairman of the Presidium of the Academy of Sciences as chairman of the Board of Directors.

Vera Rich
Spanish research

\section{Painful reform}

\section{Barcelona}

The Spanish Higher Research Council (Consejo Superior de Investigaciones Cientificas (CSIC) is nearing the end of a process aimed at giving it a fresh start. The reformers, the present directorate of CSIC, intend to demonstrate to public opinion and to the government that CSIC can renew itself and become an efficient instrument in the economic and cultural development of Spain.

CSIC is the main public body devoted to research in Spain. It has a permanent staff of 5,000 (1,500 of them scientists) in about a hundred institutes. Since its foundation and haphazard development during the government of General Franco, CSIC has maintained an enormous diversity of research interests of variable quality. There are groups devoted to local studies and to theology, to textile technology and fisheries and also to history, biology and physics. Only a few of these institutes can be compared with advanced European or American laboratories, and most of them suffer from limited and ageing staff and poor funding. This has provoked criticism from both inside and outside CSIC, directed chiefly at the low scientific level of many institutes and their lack of relevance to the general needs of the country. During the past five years of democratic government, even the aboltion of CSIC has been openly discussed.

A move to reverse this trend from inside CSIC began after the appointment of a new directorate last year. CSIC's Scientific Commission, consisting of scientists from different areas of research, was asked to suggest important areas of research and to advise laboratories how they might best pursue them. A number of commissions are now working on detailed programmes based on these suggestions. As CSIC's budget cannot finance all the programmes chosen, it is hoped that outside agencies will be able to provide additional funds. It is hoped that groups will join forces to produce plans that are likely to be financed.

CSIC scientists are anxious to give the proposed changes a chance of success, but there is some doubt about the speed at which the scheme is being carried out, particularly in the absence of any long-term decision at government level.

Increases of staff are unlikely because of cuts in public expenditure and there is doubt as to whether the proposed Law of University, including to provide guidelines for recruiting teaching and research staff, will be passed before the next elections in 1983. In the meantime, the need of people and the low level of salaries are increasing tension inside CSIC and could lead to the resignation of the present directorate. A welcome reform lies on a knife-edge.

Pedro Puigdoménech 